\title{
Safety Evaluation of Radioactive Material Transport Package under Stacking Test Condition
}

\section{방사성물질 운반용기의 적층시험조건에 대한 안전성 평가}

\author{
Ju-Chan Lee1), Ki-Seog Seo and Seong-Yeon Yoo* \\ Korea Atomic Energy Research Institute, 989-111 Daedeok-Daero, Yuseong-Gu, Daejeon \\ *Chungnam National University, 99 Daehak-ro, Yuseong-gu, Daejeon \\ 이주찬 1$)$, 서기석, 유성연* \\ 한국원자력연구원, 대전시 유성구 대덕대로 989번길 111 \\ *충남대학교, 대전광역시 유성구 대학로 99
}

(Received November 23, 2011 / Received January 11, 2012 / Approved February 08, 2012)

\begin{abstract}
Radioactive waste transport package was developed to transport eight drums of low and intermediate level waste(LILW) in accordance with the IAEA and domestic related regulations. The package is classified with industrial package IP-2. IP-2 package is required to undergo a free drop test and a stacking test. After free drop and stacking tests, it should prevent the loss or dispersal of radioactive contents, and loss of shielding integrity which would result in more than $20 \%$ increase in the radiation level at any external surface of the package. The objective of this study is to establish the safety test method and procedure for stacking test and to prove the structural integrities of the IP-2 package. Stacking test and analysis were performed with a compressive load equal to five times the weight of the package for a period of 24 hours using a full scale model. Strains and displacements were measured at the corner fitting of the package during the stacking test. The measured strains and displacements were compared with the analysis results, and there were good agreements. It is very difficult to measure the deflection at the container base, so the maximum deflection of the container base was calculated by the analysis method. The maximum displacement at the corner fitting and deflection at the container base were less than their allowable values. Dimensions of the test model, thickness of shielding material and bolt torque were measured before and after the stacking test. Throughout the stacking test, it was found that there were no loss or dispersal of radioactive contents and no loss of shielding integrity. Thus, the package was shown to comply with the requirements to maintain structural integrity under the stacking condition.
\end{abstract}

Key words : IP-2 package, low and intermediate level waste, stacking test, safety evaluation, radiation shielding

\section{요 약}

IAEA 및 국내의 방사성물질 운반 관련 규정에 따라 중 - 저준위 방사성폐기물 드럼 8개를 운반할 수 있

1) Corresponding Author. E-mail : sjclee@kaeri.re.kr 
는 IP-2형 운반용기를 개발하였다. IP-2형 운반용기는 낙하시험 및 적층시험을 거친 후 내용물의 유실 또 는 분산과 운반용기 외부표면에서의 방사선량률이 $20 \%$ 이상 증가할 수 있는 차폐능력의 상실이 없어야 한다. 본 연구의 목적은 적층시험조건에 대한 시험방법 및 절차를 수립하고 IP-2형 운반용기의 적층조건 에 대한 구조적 건전성을 평가하는데 있다. 운반용기의 원형시험모델을 이용하여 운반용기 중량의 5 배 하중으로 24 시간 동안 압축하는 적층조건에 대한 시험 및 전산해석을 수행하였다. 적층시험 시 운반용기 의 모서리기둥에서의 변형률 및 변위를 측정하였으며, 측정된 변형률 및 변위는 해석결과와 서로 일치하 였다. 컨테이너 바닥부의 처짐량은 측정이 어렵기 때문에 전산해석 방법으로 구하였다. 모서리기둥의 최 대 변위와 컨테이너 바닥의 최대 처짐은 법규에서 규정하는 허용치에 비하여 낮게 나타났다. 적층시험 전?후에는 운반용기의 외형치수, 차폐체 두께, 볼트토크 등을 측정하였으며, 그 값들을 비교분석한 결과 운반용기는 내용물의 유실 및 분산, 차폐체 두께의 감소가 나타나지 않았다. 따라서 적층시험조건에서 IP-2형 운반용기의 구조적 건전성이 입증되었다.

중심단어 : IP-2형 운반용기, 중저준위 폐기물, 적층시험, 안전성평가, 방사선차폐

\section{I. 서 론}

국내외 방사성물질 운반 관련 기준인 원자력안전위원회고시 제2011-49호[1]와 IAEA Safety Standards Series No. TS-R-1[2]에서 는 방사성물질 운반용기를 내용물의 방사능 크기 또는 형태에 따라 L형, IP형, A형 및 B형 운반용기로 구분하며, IP-2형 운반용 기의 기술기준은 다음과 같다. 운반용기의 일반기준을 만족하여 야 하며, 운반용기 외부의 최소길이는 $10 \mathrm{~cm}$ 이상이어야 한다. 운반 가능한 방사성내용물의 최대 수량은 저준위 비방사능물질 또는 표면오염물체인 경우 차폐되지 않은 상태에서 $3 \mathrm{~m}$ 지점의 방사선량률이 $10 \mathrm{mSv} / \mathrm{h}$ 에 해당하는 방사능을 초과하지 않아야 한다. 정상운반조건의 안전성시험에 따른 낙하시험 및 적층시험 을 거친 후에 방사성내용물의 유실 또는 분산이 없어야 하며, 방 사선량률이 $20 \%$ 이상 증가되는 차폐능 상실이 없어야 한다.

원자력안전위원회고시에서 규정하는 적층시험조건은 적층이 가능한 운반용기인 경우 운반물 중량의 5배 하중 또는 수직투영 면적에 $13 \mathrm{kPa}$ 을 곱한 값에 해당하는 하중으로 시험물의 마주보 는 양면에 균등하게 작용하도록 24시간 동안 압축하는 조건이 다. IP-2형 운반용기의 최대 중량이 약 6.4 톤이므로 5 배에 해당 하는 하중은 32 톤이다. 운반용기의 수직투영 면적이 $5.44 \mathrm{~m}(3.4$ $\mathrm{mx} 1.6 \mathrm{~m})$ 이므로 수직투영 면적에 $13 \mathrm{kPa}$ 을 곱하면 적용 하중 은 $70,720 \mathrm{kN}(7.2$ 톤)이다. 따라서 운반물의 5 배 하중으로 24 시간 동안 압축하는 조건에 대한 안전성 평가가 필요하다.

국토해양부고시 제2009-560호 "컨테이너 형식승인 시험 및 검정 기준”[3]에 따르면 운반 내용물을 포함한 컨테이너 1개 의 중량이 $\mathrm{R}$ 이고 적재 단수가 $\mathrm{n}$ 일 경우 컨테이너의 총 중량
$\mathrm{R}(\mathrm{n}-1)$ 이 상부 모서리에 균일하게 작용할 때 모서리기둥의 가 로 및 세로방향의 영구 좌굴 변형량이 $3 \mathrm{~mm}$ 이내, 높이방향 영구 변형량이 $3 \mathrm{~mm}$ 이내일 것을 요구하고 있다. 또한, 컨테 이너 중량의 1,8 배(1.8R)의 균일하중이 컨테이너 하부에 작용 할 때 컨테이너 바닥면의 최대 처짐이 $6 \mathrm{~mm}$ 이내일 것을 요 구하고 있다. 원자력안전위원회고시에서 규정하는 적층조건 이 운반용기 중량의 5 배 하중으로 압축하는 조건이므로 6단 적재, 즉 $n=6$ 을 적용하였다.

적층시험 조건에 대한 안전성평가는 시험적 방법과 전산해 석 방법을 통하여 수행되었다. 운반 내용물의 유실 및 운반용 기의 차폐능 상실 여부에 대한 평가는 적층시험 후 용기 뚜껑 볼트의 체결상태 및 풀림토크, 본체와 뚜껑 사이의 간극 측정 및 초음파 두께 측정기를 이용한 차폐체 두께를 측정하여 평 가하였다. 적층시험 시 레이저 변위센서, 스트레인 게이지를 설치하여 모서리기둥의 변위 및 변형률을 측정하였다. 모서 리기둥의 높이방향 영구 변형량은 변위 및 변형량을 측정을 통한 적층시험과 전산해석 방법으로 평가하였다. 모서리기둥 의 가로 및 세로방향의 영구 좌굴 변형량 및 $1.8 \mathrm{R}$ 이 되는 균일 하중이 컨테이너 하부에 작용할 때 컨테이너 바닥면의 최대 처짐은 전산해석 방법으로 평가하였다.

\section{II. 시험모델 및 방법}

\section{가. IP-2형 운반용기 시험모델}

FIP-2형 운반용기는 중 - 저준위 방사성폐기물 운반용기로 서 200리터 또는 320리터의 폐기물 드럼 8개를 운반할 수 있 
으며, 원자력안전위원회고시 제2011-49호 및 IAEA Safety Standards Series No. TS-R-1의 기준에 맞도록 설계되었다. 운 반용기의 외부제원은 길이, 폭, 높이가 각각 $3,400 \mathrm{~mm}, 1,600$ $\mathrm{mm}, 1,200 \mathrm{~mm}$ 이며, 차폐체로 사용되는 강판의 두께는 12 $\mathrm{mm}$ 이다. 운반용기의 총 중량은 드럼의 최대 중량을 $400 \mathrm{~kg}$ 을 기준으로 할 때, 6.4 톤이고 내용물을 제외한 운반용기만의 중량은 3.2 톤이다.

용기본체는 탄소강의 강재로 이루어진 직육면체의 형상으 로, 뚜껑을 열고 상부에서 크레인을 이용하여 내용물을 적재 하고, 내용물의 유출을 방지하기 위하여 운반용기의 뚜껑을 12 개의 볼트로 체결하는 구조이다. 또한 선박 및 차량에 대하 여 인양, 취급, 적재 및 결속을 위하여 ISO 1161[4]의 기준에 따른 강재 모서리쇠 및 지게차를 이용한 취급이 가능하도록 포크리프트 홈을 갖는다.

IP-2형 운반용기의 실물크기 시험모델을 제작하여 원자력 안전법에서 규정하는 시험조건에 따라 적층시험을 수행하였 다. 시험모델은 용기본체, 용기 뚜껑부, 상?하부 모서리쇠, 내 부 장입용 드럼 등으로 구성되며, 그림 1 과 표 1 은 시험모델 의 형상 및 제원을 보여준다.

\section{나. 시험방법 및 절차}

IP-2형 운반용기의 적층시험 방법은 운반용기를 편평하고 단단한 바닥에 내려놓고 그림 2와 같이 운반용기 중량의 5 배

Table 1. Dimension of IP-2 package test model.

\begin{tabular}{|c|c|}
\hline Items & Dimensions \\
\hline Outer dimension & $3,400 \times 1,600 \times 1,200 \mathrm{~mm}(\mathrm{H})$ \\
\hline Shielding thickness & $12 \mathrm{~mm}(\mathrm{t})$ \\
\hline Uper corner fitting & $172.5 \times 157 \times 116 \mathrm{~mm}(\mathrm{H})$ \\
\hline Lower coner fitting & $164.5 \times 146 \times 133.5 \mathrm{~mm}(\mathrm{H})$ \\
\hline Drum(320 $l)$ & $\Phi 680 \times 955 \mathrm{H} \times 1.2 \mathrm{~mm}(\mathrm{t})$ \\
\hline
\end{tabular}

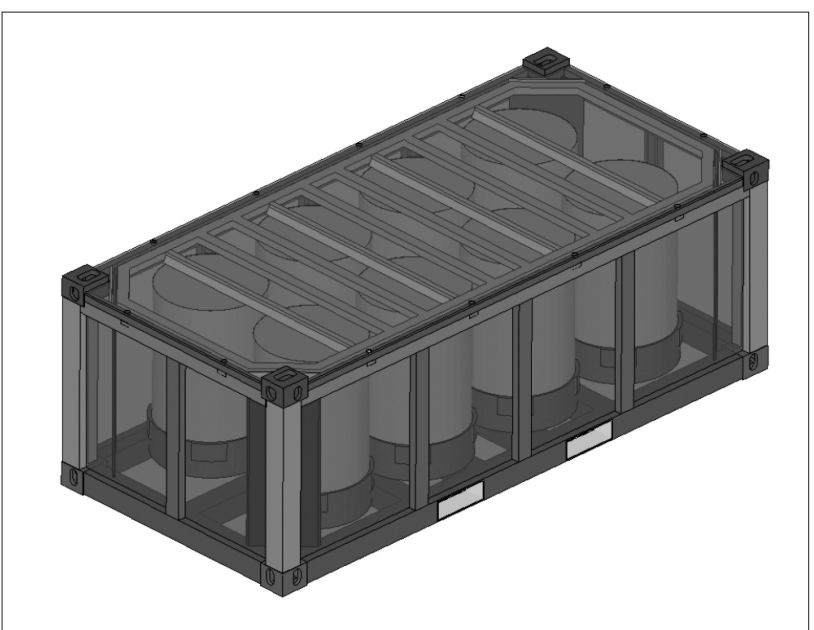

Fig. 1. Configuration of IP-2 package.
에 해당하는 하중체를 올려놓은 상태에서 24 시간 동안 압축 하는 시험이다. 운반용기의 최대 중량이 약 6.4 톤이므로 운반 용기의 5 배 중량인 32 톤의 하중체를 적재하였다. 하중체는 $120 \mathrm{~mm}$ 두께의 강판을 사용하였고 중량물이 24 시간 동안 운 반용기의 모서리쇠에 균일하게 분포되도록 하였다. 시험모델 내부에는 8 개의 모의드럼을 장전하였으며, $29.5 \mathrm{kgf} \cdot \mathrm{m}$ 의 토 크로 뚜껑 볼트를 체결하였다.

모서리기둥의 높이방향 변형량 및 변형률 측정을 위하여 그림 3, 4와 같이 레이저 변위센서 및 스트레인게이지를 설치 하였다. 그림 5는 변형량 및 변형률 측정시스템을 보여주고 있다.

운반 내용물의 유실 및 분산 여부는 적층시험 후 볼트의 체 결상태(풀림토크 측정)와 시험 전 후 용기본체와 뚜껑 사이의 간극측정 및 육안검사를 통하여 평가하였다. 용기 표면 방사 선량률이 $20 \%$ 이상 증가에 대한 차폐능 평가는 시험 전 · 후

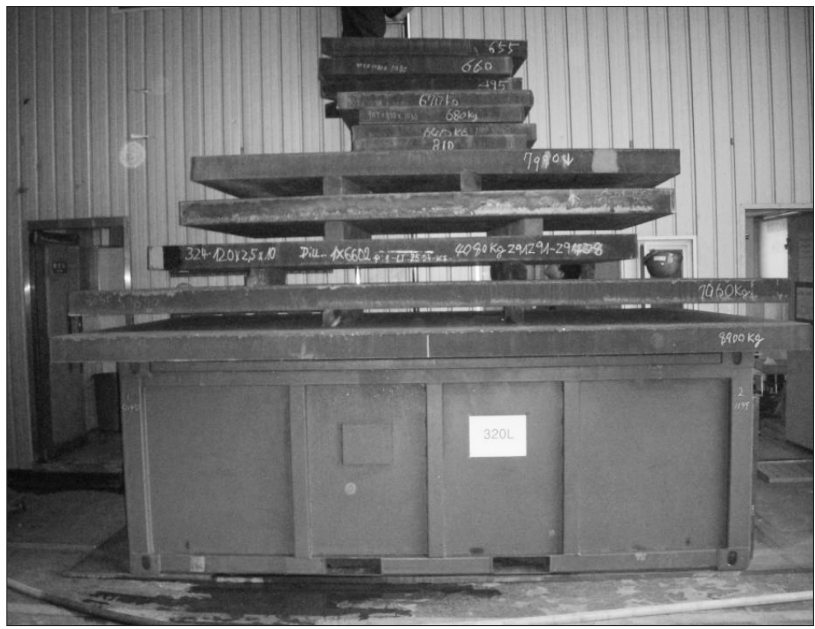

Fig. 2. Stacking test of IP-2 package.

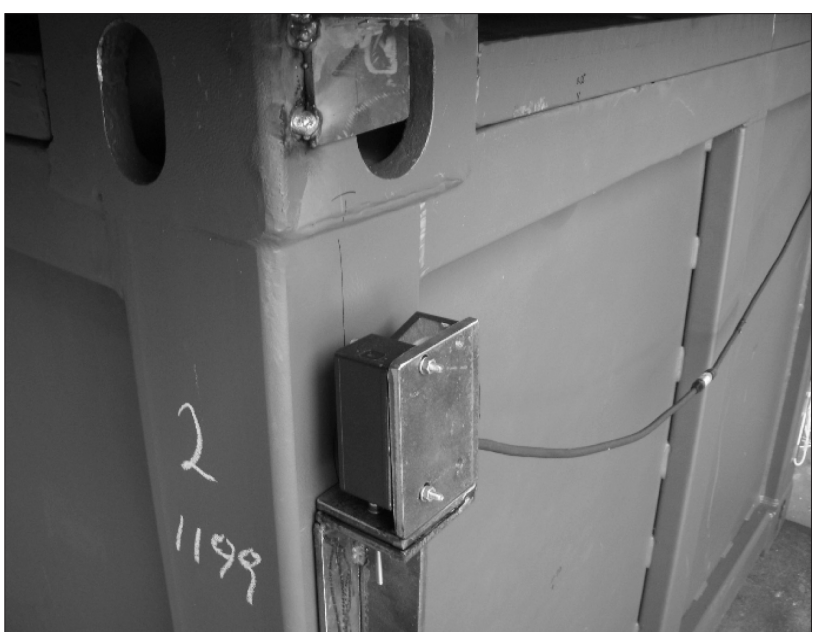

Fig. 3. Laser displacement sensor. 


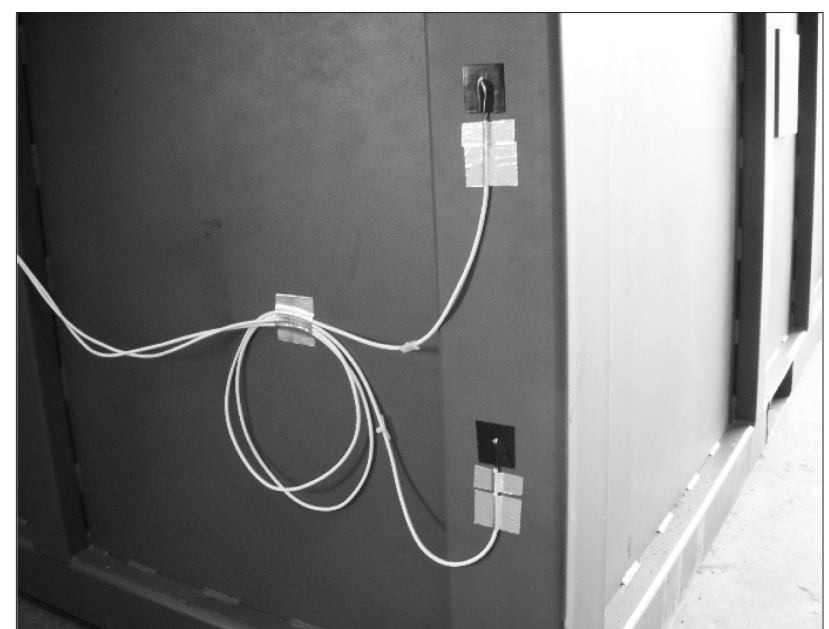

Fig. 4. Strain gauge.

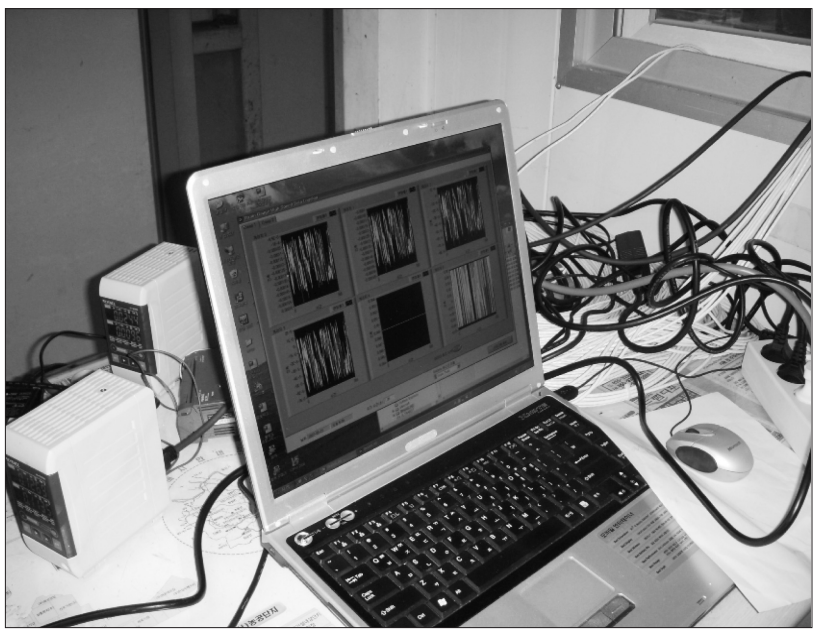

Fig. 5. Displacement and strain measuring system.

초음파 두께측정기를 이용한 차페체 두께측정과 주요 부위에 대한 치수변화를 측정하여 평가하였다. 초음파 두께측정기는 $\mathrm{JFE}$ 사의 TI- $45 \mathrm{~N}$ 모델을 사용하였으며 측정범위가 $1 \sim 200$ $\mathrm{mm}$ 이고 분해능은 $0.01 \mathrm{~mm}$ 이다.

\section{다. 적층해석}

국토해양부고시 제2009-560호에 따르면 컨테이너 총 중량 $\mathrm{R}(\mathrm{n}-1)$ 이 컨테이너 상부 모서리에 균일하게 작용할 때 모서리 기둥의 가로 및 세로방향의 영구 좌굴 변형량이 $3 \mathrm{~mm}$ 이내이 고 모서리기둥의 높이방향 영구 변형량이 $3 \mathrm{~mm}$ 이내일 것을 요구하고 있다. 모서리기둥의 가로 및 세로방향의 영구 좌굴 변형량은 전산해석을 통하여 평가하였고 모서리기둥의 높이방 향 영구 변형량은 적층시험 및 전산해석 방법으로 평가하였다.

적재중량의 1.8 배, 즉 $1.8 \mathrm{R}$ 의 균일하중이 컨테이너 하부에 작용할 때 바닥구조의 처짐은 하부 모서리쇠의 밑면으로부터
$6 \mathrm{~mm}$ 초과하지 않아야 한다고 규정하고 있다. 컨테이너 바닥 면의 최대 처짐은 측정이 어렵기 때문에 전산해석을 통하여 평 가하였다. 범용 유한요소해석 프로그램인 ABAQUS/Standard 6.7-1[5]을 이용하여 운반용기의 적층 및 적재하중에 대한 정하 중 해석을 수행하였으며, 그림 6,7 은 적층 및 적재하중 해석을 위한 전산모델을 보여주고 있다. 적층해석은 운반용기의 5 배 하중이 모서리기둥 상부에만 균일하게 분포되는 하중조건에 대한 탄성거동을 가정하였다[6]. 적재하중 해석에서도 드럼의 1.8 배 하중이 컨테이너 바닥에 균일하게 분포되는 조건을 적용 하였다. 경계조건은 모서리쇠를 완전 구속시키고 구성품들 간 에는 일반 접촉(general contact)조건을 적용하였다.

\section{III. 결과 및 논의}

적층시험 과정에서 스트레인게이지와 변위센서를 이용하

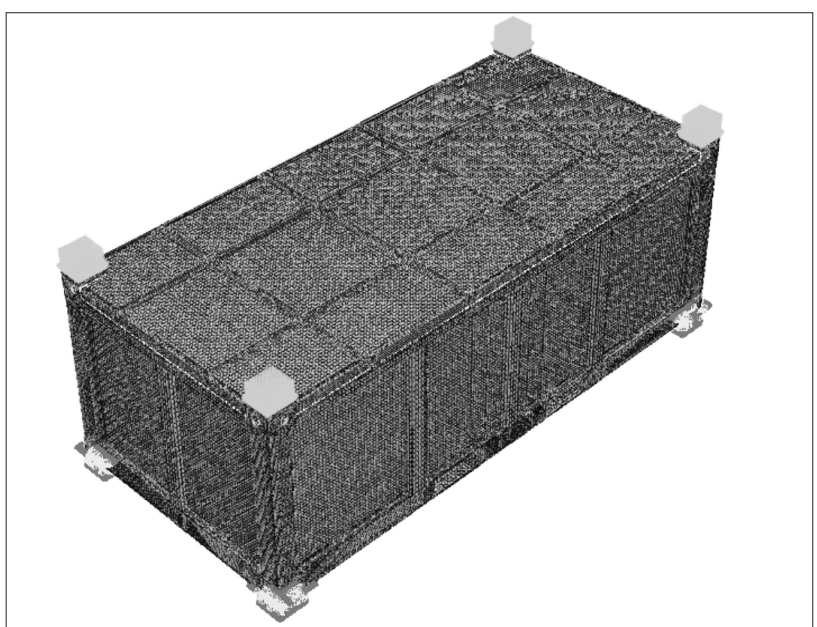

Fig. 6. Stacking analysis model.

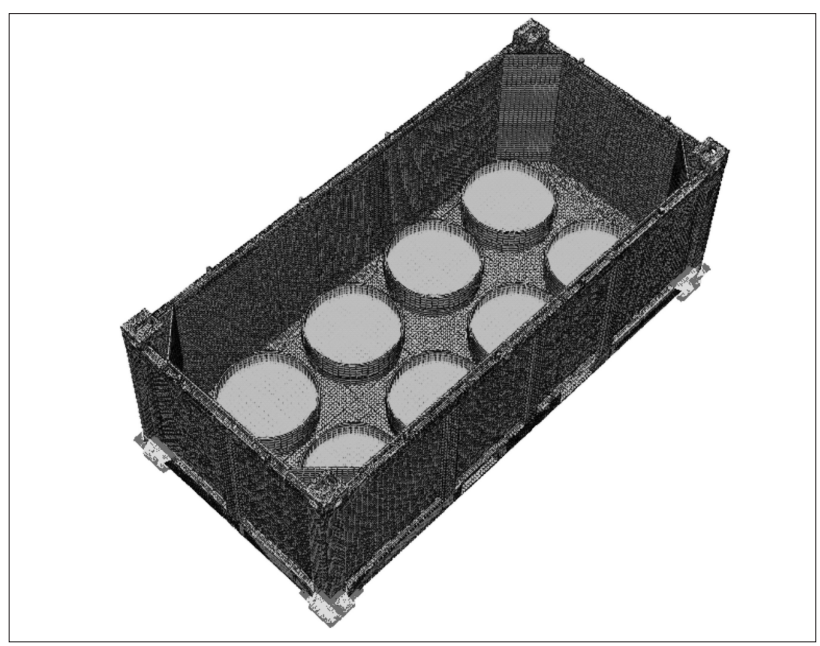

Fig. 7. Live load analysis model. 
여 모서리기둥의 변형률과 변위를 측정하였다. 그림 8은 적 층전 · 후의 변형률 변화를 나타낸다. 하중체가 적재되면서 압축으로 인한 변형률이 발생하며, 적재가 완료된 후 24시 간 동안은 거의 일정한 변형률을 보여주고 있다. 또한, 하중 체가 제거되면서 변형률이 초기값으로 원상 복귀되는 경향 을 보여주고 있다. 따라서 적층시험조건에서 운반용기는 탄 성한도 이내의 응력이 작용하는 것으로 분석되었다.

레이저 변위센서를 이용한 변위 측정결과는 그림 9와 같 다. 변위측정 결과도 변형률과 마찬가지로 하중체가 적재되 면서 모서리기둥의 압축이 발생하고 적재가 완료된 후 24시 간 동안은 거의 일정한 변위를 보여주고 있다. 또한, 하중체 가 제거되면서 변위가 초기값으로 회복되는 경향을 나타내 었다.

표 2는 IP-2형 운반용기의 적층시험 시 모서리기둥에서 측정된 변형률과 변위 측정결과를 요약하여 나타내었다. 변
형률은 $1.157 \times 10^{-4}$ 및 $1.576 \times 10^{-4}$ 로 측정되었으며, 이들 값을 변위로 환산하면 각각 $0.105 \mathrm{~mm}, 0.143 \mathrm{~mm}$ 이다. 레 이저 센서를 이용하여 측정된 변위는 $0.141 \mathrm{~mm}$ 로 변형률 측정 결과로부터 계산된 변위와 비슷한 값을 보이고 있다.

IP-2형 운반용기의 적층시험조건에서 변형률 및 변위를 간단한 관계식으로 계산하면 다음과 같다.

- 모서리기둥 단면적(A) : $27.63 \mathrm{~cm}^{2}$

- 모서리기둥 길이(L) : $91 \mathrm{~cm}$

- 탄소강의 항복강도 $\left(\sigma_{\mathrm{y}}\right): 2.4 \times 10^{3} \mathrm{~kg}_{f} / \mathrm{cm}^{2}$

- 탄소강의 탄성계수(E) : $2.1 \times 10^{6} \mathrm{~kg}_{f} / \mathrm{cm}^{2}$

Table 2. Summary of measured strain and displacement at corner fitting.

\begin{tabular}{|c|c|c|c|c|c|c|}
\hline Location & Test item & Start of test & Under test & End of test & Deviation & Displacement \\
\hline$\# 1-1$ & Strain & 0.000 & $-1.157 \times 10^{-4}$ & $1.9 \times 10^{-7}$ & $1.157 \times 10^{-4}$ & $(0.105 \mathrm{~mm})$ \\
\hline$\# 1-2$ & Strain & 0.000 & $-1.256 \times 10^{-4}$ & $3.2 \times 10^{-5}$ & $1.576 \times 10^{-4}$ & $(0.143 \mathrm{~mm})$ \\
\hline$\# 4$ & Displacement & 0.000 & $0.138 \mathrm{~mm}$ & $-0.003 \mathrm{~mm}$ & $0.141 \mathrm{~mm}$ & $0.141 \mathrm{~mm}$ \\
\hline
\end{tabular}

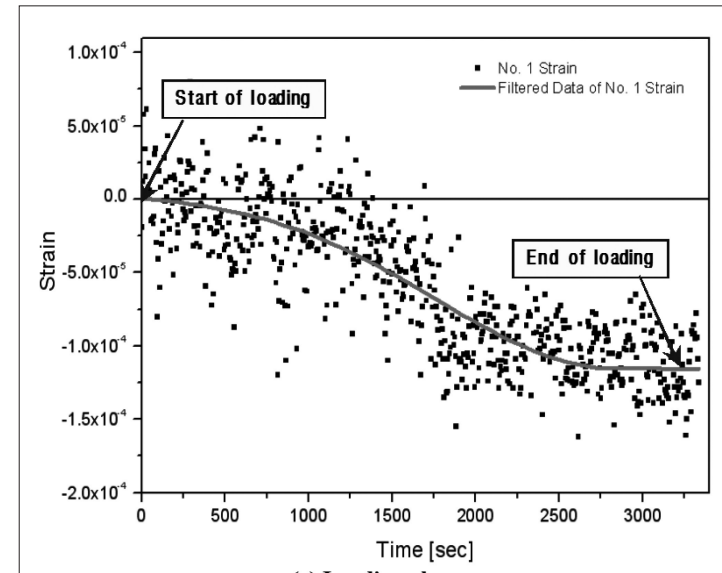

(a) Loading phase

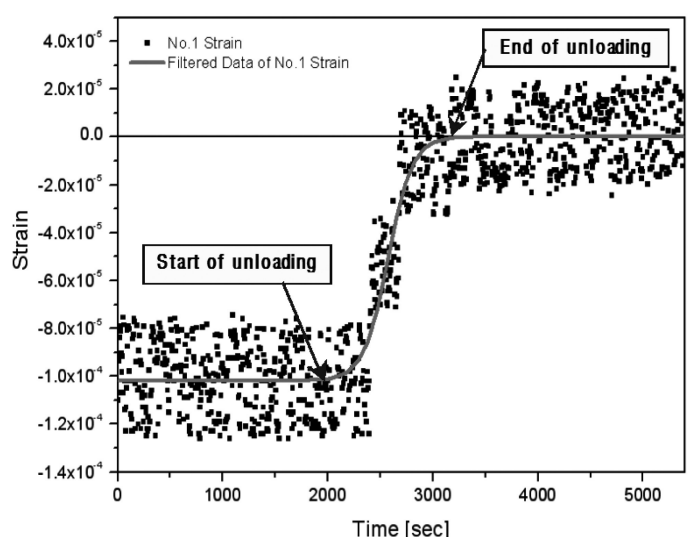

(b) Unloading phase

Fig. 8. Strain measurement result at corner fitting.

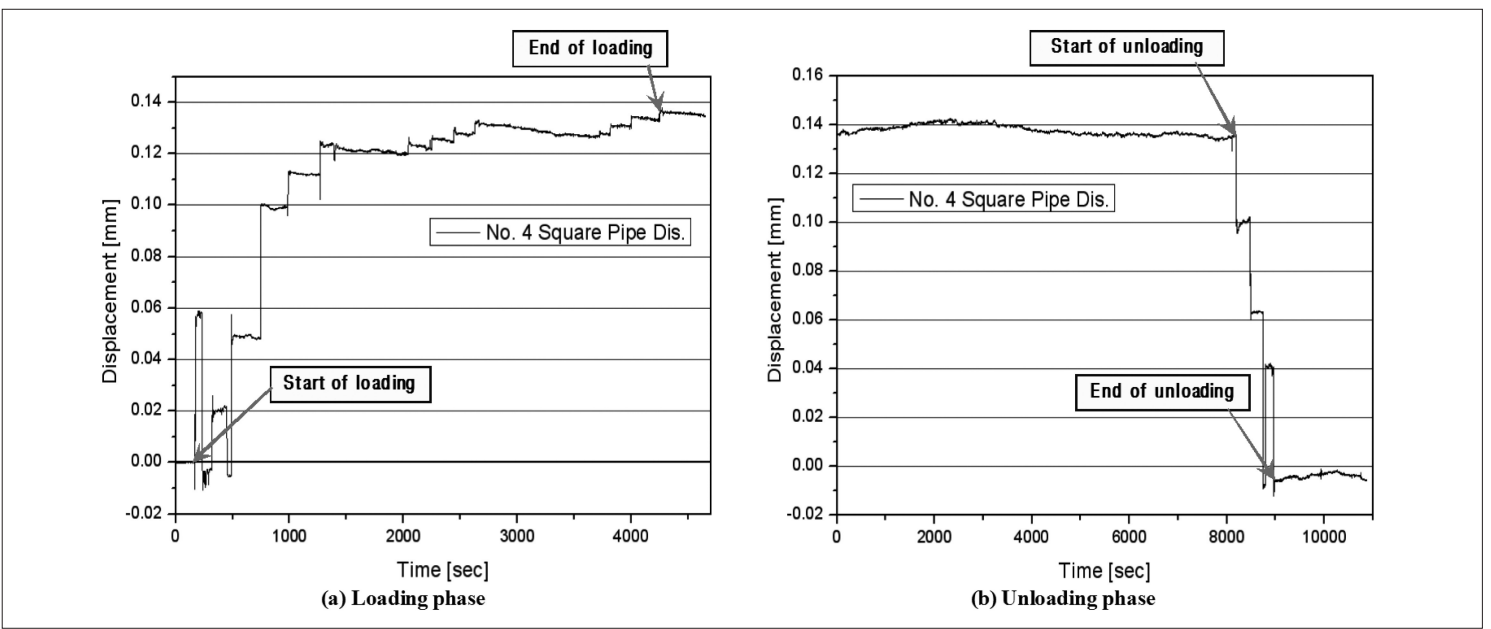

Fig. 9. Displacement measurement result at corner fitting. 
- 응력 $(\sigma): \frac{F}{A}=\frac{8000 \mathrm{kgf}}{27.63 \mathrm{~cm}^{2}}=289.5 \mathrm{kgf} / \mathrm{cm}^{2}$

[항복강도의 약 $12 \%$ 응력발생\}

- 변형률 $(\varepsilon): \frac{E}{\sigma}=\frac{289.5}{2.1 \times 10^{6}}=1.379 \times 10^{-4}$

- 변위 $(\triangle l)$ : L x $\varepsilon=91 \mathrm{~cm} \times 10^{-4}=0.0125 \mathrm{~cm}=0.125 \mathrm{~mm}$

위의 계산결과에서 운반용기 중량의 5 배 하중에 대한 적 층조건에서 모서리기둥의 응력은 $289.5 \mathrm{kgf} / \mathrm{cm}^{2}$ 으로 계산 되어 항복강도에 비하면 약 $12 \%$ 의 응력이 발생되었다. 따 라서 IP-2형 운반용기는 운반용기 중량의 약 40 배의 중량을 적재하여도 소성변형이 발생하지 않고 탄성한도 이내의 응 력이 발생하는 것으로 평가되었다. 변형률의 평균값은 측정 및 계산치가 각각 $1.367 \times 10^{-4}, 1.379 \times 10^{-4}$ 로 나타났다. 또 한, 변형량의 측정 및 계산치는 각각 $0.130 \mathrm{~mm}, 0.125 \mathrm{~mm}$ 로 $5 \%$ 이내로 일치하였다. 따라서 시험 및 계산결과에 대 한 신뢰성이 충분히 입증되었다.

적층조건에서 모서리기둥의 높이방향 변형량을 시험결과 와 비교하고, 가로 및 세로방향에 대한 변형량과 컨테이너 바닥의 최대 처짐량을 평가하기 위하여 전산해석을 수행하 였다. 그림 $10 \sim 12$ 는 적층조건에서의 3 방향에 대한 변형량 을 보여주고 있다. 전산해석 결과 높이방향의 변형량은 $0.111 \mathrm{~mm}$ 로 계산되었다. 가로 및 세로방향의 변형량은 최 대 $0.026 \mathrm{~mm}$ 로 계산되어 법규에서 규정하는 영구 변형량의 허용치 $3 \mathrm{~mm}$ 에 비하면 매우 적은 값을 보였다. 적층조건에 서의 적재하중에 최대 처짐 해석결과는 그림 13과 같다. 그 림에서 보는 바와 같이 바닥면의 중앙부에서 최대 처짐이 발생하며 그 값은 $0.231 \mathrm{~mm}$ 를 보였다. 이는 평가기준인 6 $\mathrm{mm}$ 보다 매우 적은 값으로 안전성이 충분히 확보되었음을 알 수 있다.

표 3은 적층시험조건에서 모서리기둥에 대한 변형률 및 변위의 측정결과, 수계산 및 전산해석 결과를 비교하여 나 타내었다. 표의 시험결과는 변형률 및 변위 측정값의 평균 치이며, 변형률의 측정치가 해석결과에 비하여 $12 \%$ 높게 나타났다. 변위는 측정치와 해석결과가 $17 \%$ 의 오차를 보였 다. 적층시험조건에서 모서리기둥에 발생되는 응력이 탄성 한계 이내이므로 $17 \%$ 의 오차는 비교적 만족스런 결과라 판

Table 3. Comparison of strain and displacement between stacking test and analysis.

\begin{tabular}{|c|c|c|}
\hline & Strain & Displacement \\
\hline Test value(average) & $1.367 \times 10^{-4}$ & $0.130 \mathrm{~mm}$ \\
\hline Calculation value & $1.379 \times 10^{-4}$ & $0.125 \mathrm{~mm}$ \\
\hline Analysis value & $1.220 \times 10^{-4}$ & $0.111 \mathrm{~mm}$ \\
\hline Error & $12 \%$ & $17 \%$ \\
\hline
\end{tabular}

단된다. 따라서 적층시험에서 측정된 변형률 및 변위 값에 대한 신뢰성이 입증되었다.

적층시험 전 · 후의 차폐체 두께 변화는 초음파 측정기, 본체와 뚜껑 사이의 간극 측정은 두께게이지를 이용하여 측 정하였다. 또한 토크 렌치를 이용하여 볼트토크의 변화를 측정하였으며, 시험 후 볼트를 해체한 후 내부검사를 수행 하였다. 표 4에는 IP-2형 운반용기의 적층시험 결과를 요약 하여 정리하였으며, 시험 전·후의 차폐체 두께의 감소가 발생하지 않았다. 또한 용기본체와 뚜껑 사이의 간극이 1.85 $\mathrm{mm}$ 로 본체와 뚜껑의 단차 $40 \mathrm{~mm}$ 에 비하여 훨씬 적게 측정 되었으며, 볼트의 체결상태도 양호하게 유지되었다. 따라서 IP-2형 운반용기는 적층시험조건에서 법규에서 요구하는 운 반 내용물의 유실 및 차폐체의 손상이 발생하지 않고 구조 적 건전성이 충분히 유지될 것으로 판단된다.

\section{IV. 결 론}

본 연구에서는 국내외 운반관련 법규에서 요구하는 방사 성물질 운반용기의 시험요건 중에서 적층시험조건에 대한 시험방법 및 절차를 수립하였으며, 시험 및 전산해석 방법 을 이용하여 IP-2형 운반용기의 적층조건에 대한 안전성을 평가하였다.

적층시험에서 측정된 운반용기 모서리기둥의 높이방향에 대한 변형량을 수계산, 전산해석 결과와 비교하였으며, 측 정 및 해석결과가 최대 $17 \%$ 의 오차를 보였지만 모서리기둥 에 발생되는 응력이 탄성한계 이내이므로 시험 및 해석결과 에 대한 신뢰성이 유지되는 것으로 평가되었다. 모서리기둥 의 높이방향 최대 변형량은 약 $0.14 \mathrm{~mm}$ 로 법규에서 규정하 는 허용기준인 $3 \mathrm{~mm}$ 이내로 평가되었다. 적층해석 결과에 서 모서리기둥의 가로 및 세로 방향의 변형량도 최대 0.026 $\mathrm{mm}$ 계산되어 허용치인 $3 \mathrm{~mm}$ 이내로 평가되었다. 컨테이 너의 내부 적재하중에 대한 해석결과 컨테이너 바닥의 최대 처짐량은 약 $0.231 \mathrm{~mm}$ 로 계산되어 허용치인 $6 \mathrm{~mm}$ 이내로

Table 4. Summary of stacking test results for IP-2 package.

\begin{tabular}{|c|c|c|c|}
\hline Measurement item & Test result & Allowable value & Remarks \\
\hline $\begin{array}{c}\text { Displacement of vertical direction at } \\
\text { the corner fitting (mm) }\end{array}$ & 0.14 & 3.0 & Satisfaction \\
\hline $\begin{array}{c}\text { Displacement of lateral direction at } \\
\text { the corner fitting (mm) }\end{array}$ & 0.026 & 3.0 & Satisfaction \\
\hline Max. deflection of base plate (mm) & 0.231 & 6.0 & Satisfaction \\
\hline $\begin{array}{c}\text { Average variation of shielding } \\
\text { thickness (mm) }\end{array}$ & \pm 0.01 & -6.0 & Satisfaction \\
\hline $\begin{array}{c}\text { Maximum gap between package lid } \\
\text { and body (mm) }\end{array}$ & 1.85 & $\begin{array}{c}40.0(\text { difference } \\
\text { of lid level) }\end{array}$ & Satisfaction \\
\hline $\begin{array}{c}\text { Average release torque of lid bolts } \\
\text { (N-m) }\end{array}$ & 245 & 289.1 & Satisfaction \\
\hline Damage or release of lid bolts & No & No & Satisfaction \\
\hline Loss of radioactive contents & No & No & Satisfaction \\
\hline
\end{tabular}




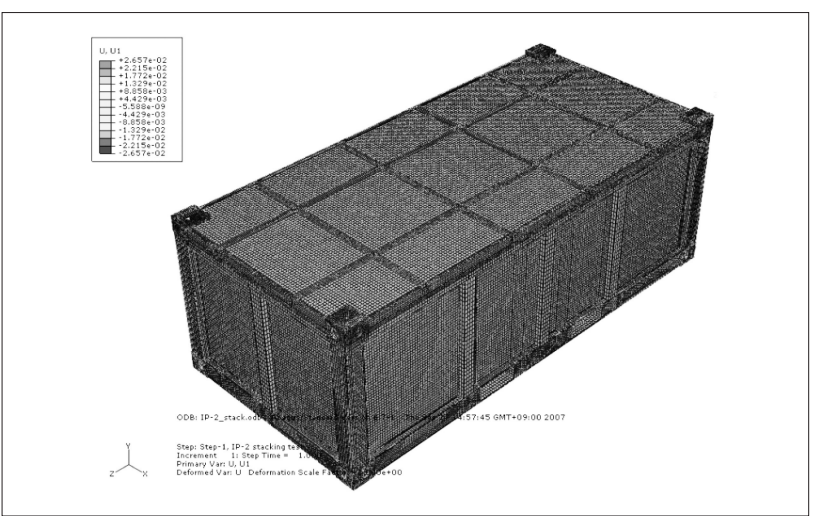

Fig. 10. Deformation of X-direction.

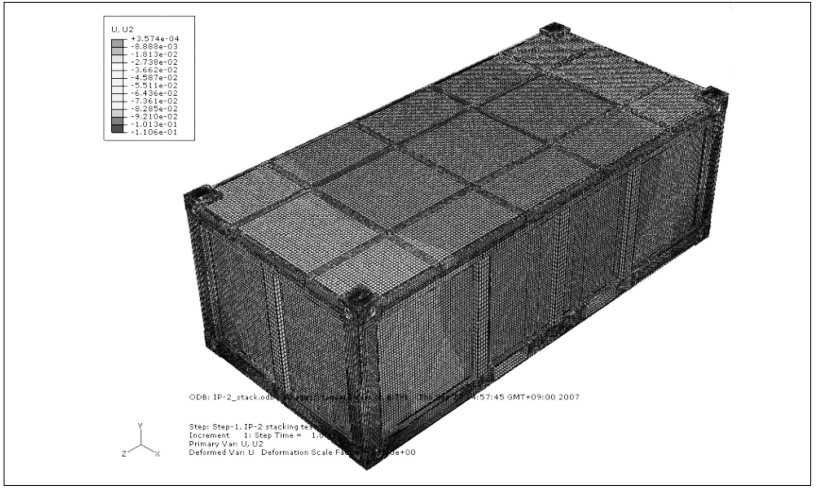

Fig. 11. Deformation of Y-direction.

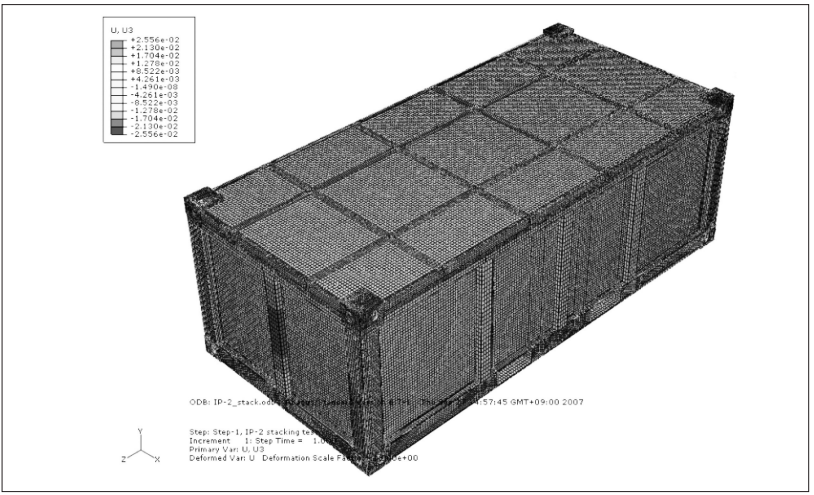

Fig. 12. Deformation of Z-direction.

평가되었다.

적층시험 전 · 후에 운반용기의 외형치수, 차폐체 두께, 볼트토크 등을 측정하였으며, 그 값들을 분석한 결과 운반 용기는 내용물의 유실 및 분산, 차폐체 두께의 감소가 발생 하지 않았다. 따라서 IP-2형 운반용기는 적층시험조건에서 원자력안전위원회고시의 운반용기 기술기준 및 국토해양부 고시의 일반 컨테이너 형식승인 기술기준을 모두 만족하여 구조적 건전성이 입증되었다.

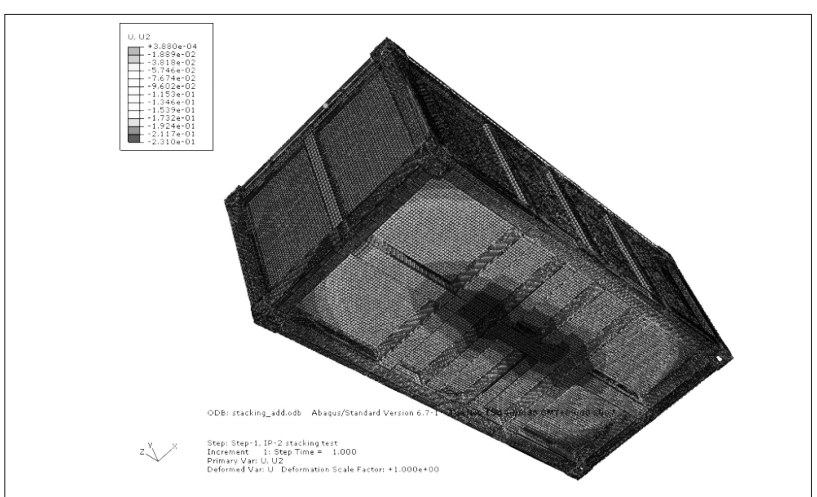

Fig. 13, Deflection of base plate.

\section{References}

[1] NSC Notice No 2011-49, "Regulation for Packaging and Transportation of Radioactive Materials", Nuclear Safety and Security Commission Notice, 2011.

[2] IAEA Safety Standards Series No, TS-R-1, "Regulations for the safe transport of radioactive material", 2009.

[3] MLTM Notice No. 2009-560, "Criteria for Type Approval Test and License of Container", Ministry of Land, Transport and Maritime Affairs, 2009.

[4] ISO 1161, "Series 1 Freight Containers - Corner Fittings - Specification, International Organization for Standardization, (1984).

[5] ABAQUS User's Manual for Revision 6.7.1, Hibbit, Karlson \& Sorenson Inc., (2007).

[6] Sang-Jin Lee, D. H. Kim, K. H. Lee, J. M. Kim, and K. S. Seo, "Structural Safety Test and Analysis of Type IP-2 Transport Packages with Bolted Lid Type and Thick Steel Plate for Radioactive Waste Drums in a NPP", J. of the Korean Radioactive Waste Society Vol5(3), P.199-212, 2007. 